\title{
NEW SUNFLOWER RESTORER LINES DEVELOPED \\ BY DIRECT ORGANOGENESIS METHOD FROM INTERSPECIFIC CROSS Helianthus annuus L. (cv. ALBENA) $\times$ Helianthus salicifolius L.-DISEASE RESISTANCE, COMBINING ABILITY
}

\author{
Encheva, J. , Christov, M., Shindrova, P., Drumeva, M. and Encheva, V.
}

Dobroudja Agricultural Institute-General Toshevo, 9520

Received: January 31, 2006 Accepted: December 05, 2006

\section{SUMMARY}

The direct organogenesis method in immature $F_{1}$ embryos from sunflower was successfully applied for production of new forms from the interspecific cross Helianthus annuus (cv. Albena) $\times$ Helianthus salicifolius. After repeated selfing and continuous selection, a great diversity of new sunflower lines were developed. Some of the new lines possessed resistance to Phomopsis, Phoma, Alternaria and the parasitic angiosperm broomrape as well as very good combining ability. The hybrids developed from the new lines showed increases of the indices for seed and oil yields of $114.0 \%$ and $117.8 \%$, respectively, compared with the mean standard (commercial hybrids Albena and Super Start), short vegetation period and reduced height. Combinations of these favorable changes are desirable in breeding work on sunflower.

Key words: sunflower, Helianthus salicifolius, direct organogenesis, disease resistance, combining ability

\section{INTRODUCTION}

An investigation on the productivity of cultivated sunflower showed that diseases are the most important limiting factor in the majority of countries producing sunflower. The widely spread diseases such as Phomopsis helianthi, Phoma macdonaldii, Alternaria helianthi and Plasmopara helianthi and the parasite Orobanche cumana drastically decrease sunflower yield especially in Central and Southern Europe. Wild Helianthus species are a potential source of genes for resistance to diseases (Škorić, 1987, Christov, 1990, Sackston, 1992; Seiler, 1992; Škorić and Rajčan, 1992; Škorić, 1995; Georgieva-Todorova, 1993, 1997).

\footnotetext{
* Corresponding author: e-mail: july_262002@yahoo.com
} 
Application of new biotechnology methods can help in exceeding the present problems in interspecific hybridization of sunflower. By using the embryo culture method, hybrid plants resistant to Phomopsis helianthi (Dozet et al., 1996) and partially resistant to Sclerotinia (Köhler at al., 1999) were produced as a result of crossing cultivated sunflower with the wild species Helianthus tuberosus. With the help of the direct organogenesis method, hybrid plants resistant to Orobanche cumana were developed from crossing with the wild species Helianthus tuberosus (Encheva et al., 2004).

The embryo rescue technique is most commonly used for overcoming the incompatibility between $H$. annuus L. and different alien species (Chandler and Beard, 1983; Kräuter et al., 1991; Bohorova et al., 1991; Friedt, 1992; Korell et al., 1996a). However, it does not always contribute to the production of hybrid plants. This moved us to investigate possibilities of the direct organogenesis method, which has not been applied before, as an approach for overcoming the interspecific and intergeneric incompatibilities in sunflower hybridization (Encheva et al., 1992). In comparison with the authors mentioned above, this study presents data on hybrid progenies in an advanced generation, as well as data on their combining ability.

The aim of this study was: a) to follow the reaction to the diseases Phomopsis helianthi, Phoma macdonaldii, Alternaria helianthi and Plasmopara helianthi and a local population of the parasite Orobanche cumana of the $\mathrm{F}_{10}$ hybrid progenies of the cross $H$. annuus (cv. Albena) $\times$ Helianthus salicifolius produced through the direct organogenesis method, and $\mathrm{b}$ ) to investigate the combining ability of the new fertility restorer lines (R) against $H$. petiolaris cytoplasm.

\section{MATERIALS AND METHODS}

Cultivated sunflower (hybrid Albena-2n=34) and the wild species Helianthus salicifolius, accession M-078 $(2 \mathrm{n}=34)$, were grown under field conditions at DAIGeneral Toshevo. Hybrid embryos were obtained by sterilizing the pollen of the female parent (hybrid Albena) with gibberellic acid and by hand pollination of the female plants with pollen from the male parental form, Helianthus salicifolius.

Direct somatic buds and plants were induced on nutrition media I, II and III (Encheva et al., 1992). Electrophoretic studies confirmed the hybrid character of the obtained plants (Encheva et al., 1992). As a result from repeated selfing and continuous individual selection in the hybrid materials, fertility restorer lines were produced in the $\mathrm{F}_{10}$ generation. All hybrid materials possessed a $\mathrm{cms}$ source of $H$. petiolaris from Leclerq (1969). In the crosses made, the female form had sterile cytoplasm of $H$. petiolaris and, therefore, only fertile forms were considered in this research, i.e., the ones possessing a gene for restoration. The origin of this gene has not been proved by us. It may originate from both the female form - hybrid Albena, 
and the wild male parent; there was evidence for the latter that it carries genes for restoration of this cytoplasm (Christov, 1996; Christov et al., 1996).

\section{The phytopathological evaluation}

The phytopathological evaluation of the parental forms and the obtained hybrid progenies was performed with regard to the local broomrape (Orobanche cumana Wallr.) population and Phomopsis (Phomopsis helianthi, Munt.-Cvet. et al.), phoma (Phoma macdonaldii, Boerema/Phoma oleracea var. helianthi-tuberosi Sacc), Alternaria (Alternaria helianthi) and Downy mildew (Plasmopara halstedii (Farl.) Berl. \& de Toni) at the Sunflower Phytopatology Laboratory and infection fields of DAI - General Toshevo. The evaluation was carried out in the period 19971999 , following the standard methodologies. The estimation of resistance to Phomopsis was performed 20 days after inoculation of plants at budding stage (Tourvieille et al., 1988). A six-degree scale was used:

- 0 = healthy plant;

- $1=$ spots on the stem located around the leaf petiole;

- 2 = spots reaching up to $5 \mathrm{~cm}$;

- 3 = spots girdling the stem;

- $4=$ full necrosis of the pith and

- 5 = broken stems.

Intensity of infection with Alternaria and Phoma was estimated on the scale 0-4, in the infection field (Iliescu, 1992). The reaction of sunflower genotypes to broomrape was examined in the greenhouse using a technique described by Panchenko (1973). The reaction of 20 plants from each genotype was recorded using the following scale: $0 \%=\mathrm{S}$ (sensitive); $100 \%=\mathrm{R}$ (resistant). The method for determining the reaction of sunflower genotypes to downy mildew was described by Viranyi and Gulya (1995). Reaction of 20 plants from each genotype was recorded using the following scale: $0 \%=\mathrm{S}$ (sensitive); $100 \%=\mathrm{R}$ (resistant).

\section{Biometric evaluation and biochemical analysis of hybrids 56, 81 and 88 developed from the new lines R107, R114 and R120}

The biometric evaluation and biochemical analysis of the main agronomic characters of the new developed hybrids, seed yield and oil yield, were made on 30 plants in three replications for each individual year. Nuclear-magnetic resonance (Newport Instruments Ltd., 1972) was used to determine oil content in air-dry seeds of the developed hybrids.

\section{Hybridization}

To determine the combining ability of the newly developed sunflower restorer lines, a sterile analogue of the Bulgarian selfed line ms2607 was used. The standards for comparing the new hybrids 56, 81 and 88 were the Bulgarian commercial hybrids Albena and Super Start. The obtained hybrid combinations were tested for 
two years (1997 and 1999) at the breeding fields of DAI according to the blockdesign method, in three replications, the area of each replication being $10 \mathrm{~m}^{2}$ (Barov and Shanin, 1965).

\section{RESULTS AND DISCUSSION}

\section{A) Evaluation of the materials for some economically important diseases and parasites on sunflower}

In most countries where sunflower is grown commercially, successful production is endangered by many fungal pathogens and parasites. Losses may be severe, near $100 \%$, or even entire fields may perish under extreme circumstances.

Lines R107, R114 and R120 were considerably important as initial breeding material for sunflower selection and for hybrid seed production because in addition to resistance to some economically important diseases and parasite broomrape, they possessed very good combining ability.

The phytopathological evaluation of the parental form Albena and the obtained hybrid progenies was performed with regard to the local broomrape population and the diseases Phomopsis, Phoma, Alternaria and Downy mildew. The results from the three-year testing of promising $\mathrm{R}$ lines are given in Table 1. The 1997-1999 data show complete resistance to Phomopsis and 100\% resistance to Downy mildew, as well as tolerance to Phoma of line R 114. Resistance to Altenaria and tolerance to Phoma were observed in line R120. The resistance of lines R114 and R120 to some of the economically important diseases probably comes from the wild species $H$. salicifolius which, according to the investigations of Christov, 1990, 1996 and Christov et al., 1996, has shown complete resistance to Downy mildew, Phomopsis and Phoma. Among the sources of resistance to phomopsis and alternaria, Škorić, 1987, pointed out $H$. salicifolius. The female form (hybrid Albena) is, on its part, susceptible to the diseases mentioned above, with the exception of downy mildew.

Table 1: Evaluation of advanced $\mathrm{R}$ lines from the interspecific hybrids $H$. annuus $\times$ Helianthus salicifolius and parental forms for resistance to Phomopsis, Phoma, Alternaria, Downy mildew race 300 (1997-1999) and Broomrape (1999)

\begin{tabular}{|c|c|c|c|c|c|c|c|c|c|c|c|c|c|}
\hline \multirow{3}{*}{ Variant } & \multicolumn{13}{|c|}{ Year } \\
\hline & \multicolumn{4}{|c|}{1997} & \multicolumn{4}{|c|}{1998} & \multicolumn{5}{|c|}{1999} \\
\hline & $\bar{a}$ & $\mathrm{~b}$ & C & $\mathrm{d}$ & $\mathrm{a}$ & $\mathrm{b}$ & C & $d$ & $\mathrm{a}$ & $\mathrm{b}$ & $\mathrm{C}$ & d & $\mathrm{e}$ \\
\hline hybrid Albena & 2 & $2 / 3$ & 2 & 100 & 2 & $2 / 3$ & 2 & 100 & 2 & $2 / 3$ & 2 & 100 & 0 \\
\hline H. salicifolius M-087 & 0 & 0 & 0 & 100 & 0 & 0 & 0 & 100 & 0 & 0 & 0 & 100 & $100 \%$ \\
\hline $\mathrm{R} 107$ & 2 & $2 / 3$ & 2 & 100 & 2 & $2 / 3$ & 2 & 100 & 2 & $2 / 3$ & 2 & 100 & $100 \%$ \\
\hline $\mathrm{R} 114$ & 0 & $1 / 3$ & 2 & 100 & 0 & $1 / 3$ & 2 & 100 & 0 & $1 / 3$ & 2 & 100 & 0 \\
\hline $\mathrm{R} 120$ & 2 & $1 / 3$ & 0 & 100 & 2 & $1 / 3$ & 0 & 100 & 1 & $1 / 3$ & 0 & 100 & 0 \\
\hline
\end{tabular}

Key: a) Phomopsis (scale 0-4); b) Phoma (scale 1/3-3/3);

c) Alternaria (scale 0-4); d) Downy mildew (scale 0-100\%);

e) Broomrape (scale 0-100\%) 

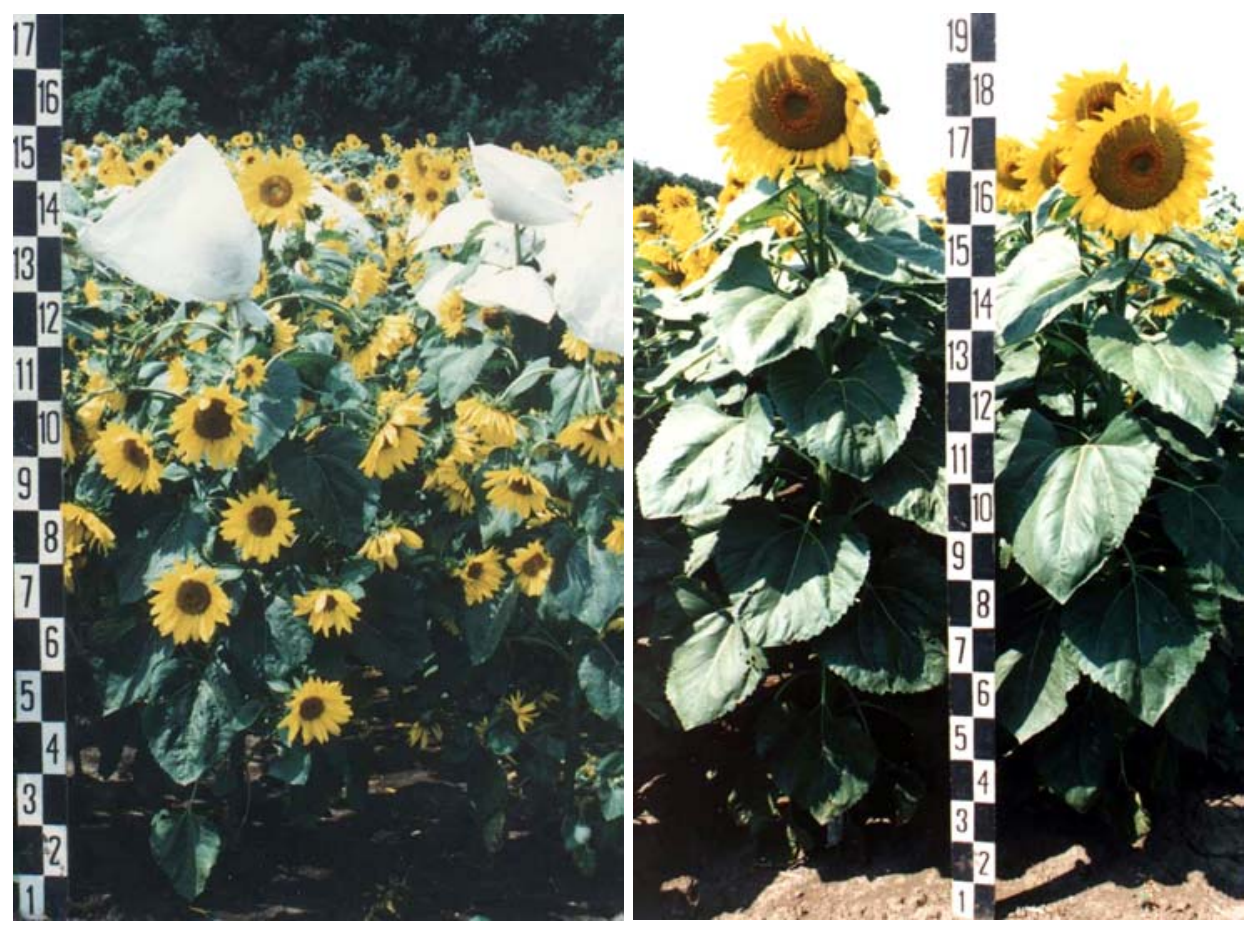

Figure 1: Line R107 from the cross $H$. annuus $(c v$. Albena) $\times H$. salicifolius

Figure 2: Hybrid 81 from the cross ms2607 × line R107

Figure 3: Hybrid 88 from the cross ms2607 × line R114

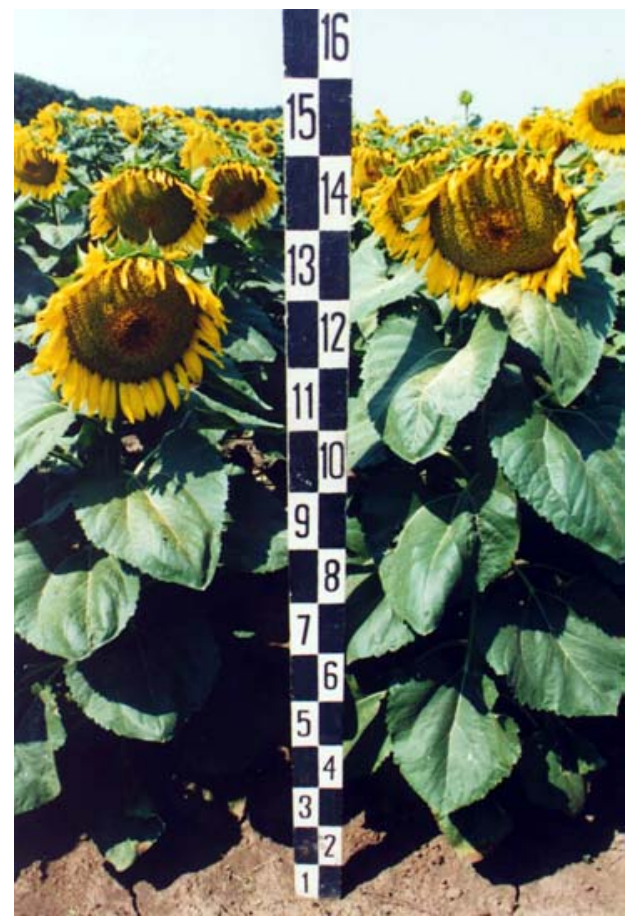


Broomrape is a major parasite in various parts of Europe, and especially in Spain, the Near East and China (Škorić, 1994). Therefore, development of new lines resistant to this parasite is essential for sunflower breeding. As a result of interspecific hybridization, line R107 was developed, which showed 100\% resistance to broomrape against artificial infection background. The resistance of line R107 comes from the wild species $H$. salicifolius, which, according to Christov et al. (1996), has complete resistance to the parasite under both field and laboratory conditions.

\section{B) Investigation on the productive potential of test hybrids developed from self pollinated sunflower lines from the cross $H$. annuus $\times$ Helianthus salicifolius}

The results from the two-year testing of the test hybrids of the lines developed by the direct organogenesis method from the interspecific hybrid $H$. annuus (hybrid Albena) $\times H$. salicifolius are presented in Figures 4-5 and Tables 2-3. The sterile analogue of the Bulgarian line 2607 was used as a tester.

Lines R107 (Figure 1) and R114 participated in the development of hybrids 81 (Figure 2) and 88 (Figure 3 ). The two-year testing revealed the very good production potential of the two hybrids.

Averaged for the two years, hybrid 81 gave a higher seed yield, by $37.0 \mathrm{~kg} / \mathrm{dka}$ or $12.4 \%$, than the mean standard (Figure 4 ). Hybrid 88 gave a higher seed yield than the standard, by $32.5 \mathrm{~kg} / \mathrm{dka}$ or $110 \%$. These differences were highly significant.

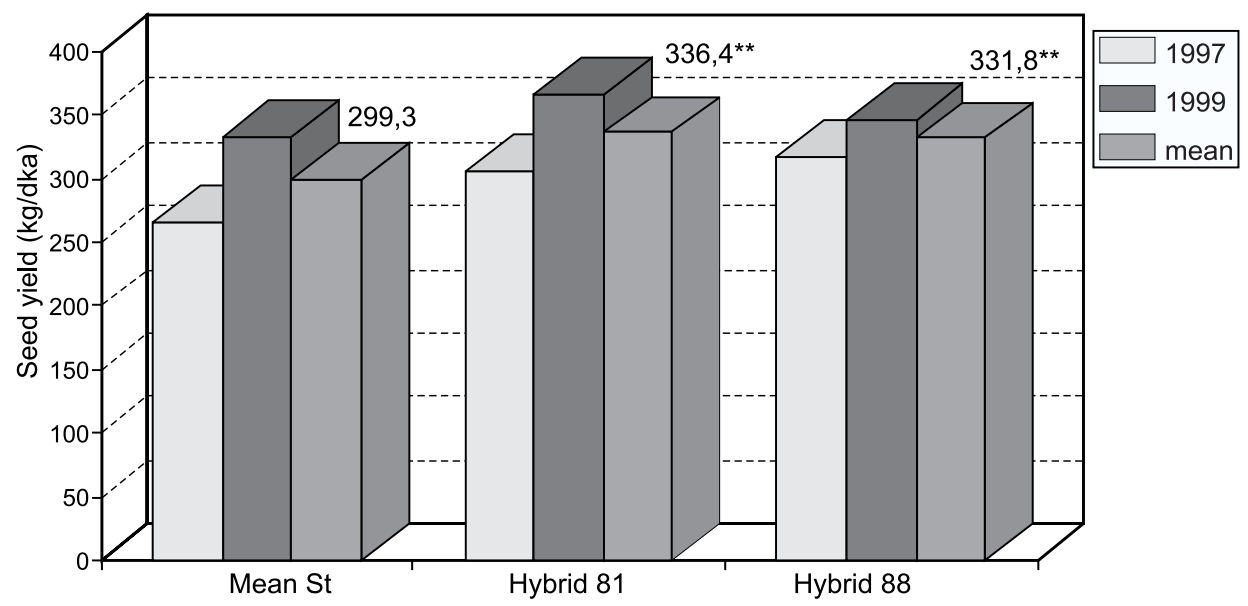

Figure 4: Comparison of seed yields of hybrids 81 and 88 and the mean standard (commercial hybrids Albena and Super Start) during 1997 and 1999 (**P=0.1\%)

The data for oil yield (Figure 5 ) show that hybrid 81 exceeded the mean standard by $20 \mathrm{~kg} / \mathrm{dka}$ or $15.2 \%$. The oil yield of hybrid 88 was higher by $22.4 \mathrm{~kg} / \mathrm{dka}$ or $14.0 \%$. The results for hybrid 81 were highly significant. 


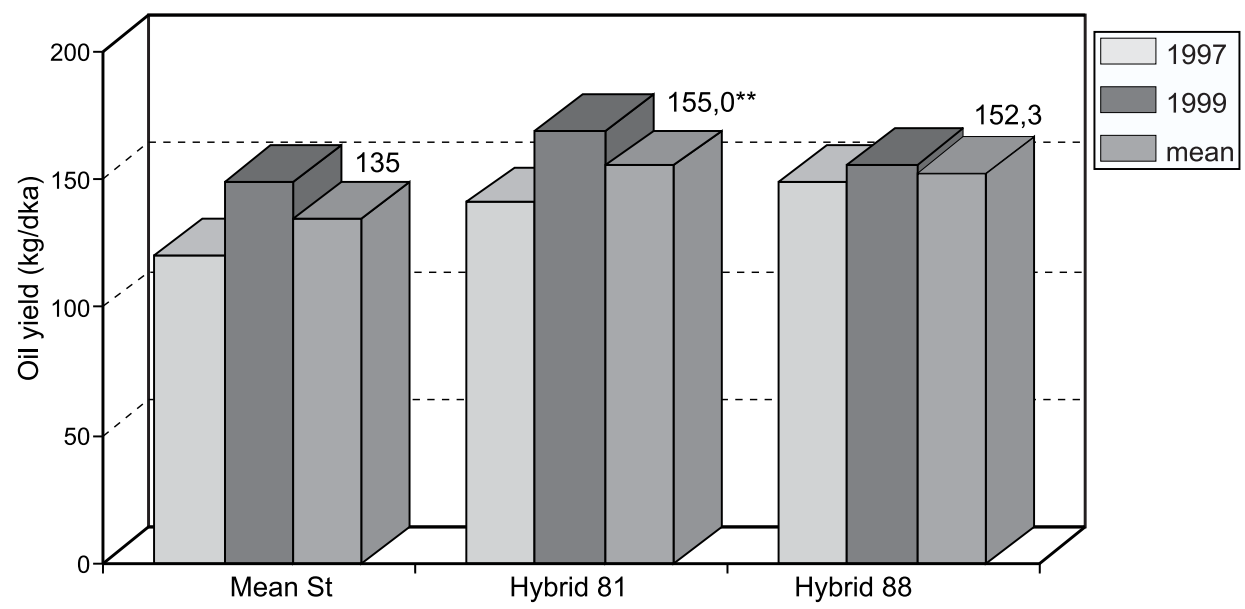

Figure 5: Comparison of oil yields of hybrids 81 and 88 and the mean standard (commercial hybrids Albena and Super Start) during 1997 and 1999 ( $\left.{ }^{* *} P=0.1 \%\right)$

Table 2 provides data on the vegetation period and plant height for the two test hybrids. A statistically significant decrease of the vegetation period, by 4 days on average for the two years, was observed in hybrid 88. This hybrid showed the most significant decrease of plant height, by $19.5 \mathrm{~cm}$, compared with the standard (Albena and Super Start) (Table 2). A significant difference of $4.5 \mathrm{~cm}$ was also observed in hybrid 81 in 1999.

Table 2: Phenological observation and morphological characterization of test hybrids 81 and 88 developed from lines R107 and R114, respectively; averaged data

\begin{tabular}{|c|c|c|c|c|c|c|c|}
\hline Hybrid, year & \multirow[t]{2}{*}{ Cross } & \multicolumn{3}{|c|}{$\begin{array}{c}\text { Vegetation period } \\
\text { difference against } \\
\text { the mean standard, days }\end{array}$} & \multicolumn{3}{|c|}{$\begin{array}{c}\text { Plant height } \\
\text { difference against } \\
\text { the mean standard, } \mathrm{cm}\end{array}$} \\
\hline 19971999 & & 1997 & 1999 & mean & 1997 & 1999 & mean \\
\hline No 47 No 81 & $\mathrm{~ms} 2607 \times \mathrm{R} 107$ & -3 & +2 & -1 & -3.3 & $-4.5^{\star}$ & -4 \\
\hline No 52 No 88 & $\mathrm{~ms} 2607 \times \mathrm{R} 114$ & -5 & -3 & $-4^{*}$ & -19.8 & -19.2 & $-19.5^{\star \star \star}$ \\
\hline
\end{tabular}

The indices for oil content in seed (\%) and head diameter are given in Table 3. A high oil percentage was registered in hybrid $81,3.4 \%$ above the standard. A considerable decrease, $1.4 \mathrm{~cm}$, was determined in hybrid 81 with regard to the index for head diameter. The differences in both characters were not significant.

Table 3: Biochemical and morphological characterization of test hybrids 81 and 88 developed from lines R107 and R114, respectively; averaged data

\begin{tabular}{|c|c|c|c|c|c|c|c|}
\hline Hybrid, year & \multirow[t]{2}{*}{ Cross } & \multicolumn{3}{|c|}{$\begin{array}{c}\text { Seed oil content } \\
\text { difference against } \\
\text { the mean standard,\% }\end{array}$} & \multicolumn{3}{|c|}{$\begin{array}{c}\text { Head diameter } \\
\text { difference against } \\
\text { the mean standard, } \mathrm{cm}\end{array}$} \\
\hline 19971999 & & 1997 & 1999 & mean & 1997 & 1999 & mean \\
\hline No 47 No 81 & $\mathrm{~ms} 2607 \times \mathrm{R} 107$ & 104.0 & 102.7 & 103.4 & -2.3 & -0.5 & -1.4 \\
\hline No 52 No 88 & $\mathrm{~ms} 2607 \times \mathrm{R} 114$ & 106.0 & 100.0 & 102.2 & -0.8 & -0.4 & -0.6 \\
\hline
\end{tabular}


Beside the above advantages over the mean standard for seed and oil yield, hybrid 81 also showed $100 \%$ resistance to the parasite Orobanche in a test against an artificial infection background conducted in 1999. The resistance of hybrid 81 to Orobanche probably comes from line R107, which is $100 \%$ resistant to the parasite. Hybrid 81 resulted from the cross ms $2607 \times \mathrm{R} 107$ and the resistance to broomrape was probably determined by the dominant gene in the male line, since the female line ms2607 is not resistant to the parasite.

The one-year results for test hybrid 56 developed from line R120 (Table 4) showed higher values than the mean standard for seed yield and oil yield, by $14.0 \%$ and $17.4 \%$, respectively. These differences were not significant. Highly significant decreases of plant height (by $29.5 \mathrm{~cm}$ ) and vegetation period (7 days) were observed.

Table 4: Biochemical and morphological characterization and phenological observations of test hybrid 56 developed from line R120 (1997); averaged data, difference against the mean standard

\begin{tabular}{llccccccc}
\hline \multirow{2}{*}{ Hybrid } & \multicolumn{2}{c}{ Seed yield } & \multicolumn{2}{c}{ Oil yield } & \multicolumn{2}{c}{$\begin{array}{c}\text { Plant } \\
\text { height }\end{array}$} & $\begin{array}{c}\text { Head } \\
\text { diameter }\end{array}$ & $\begin{array}{c}\text { Vegetation } \\
\text { period }\end{array}$ \\
\cline { 2 - 9 } & & $\mathrm{kg} / \mathrm{dka}$ & $\%$ & $\mathrm{~kg} / \mathrm{dka}$ & $\%$ & $(\mathrm{~cm})$ & $(\mathrm{cm})$ & (days) \\
\hline No 56 & $\mathrm{~ms} 2607 \times \mathrm{R} 120$ & 303.8 & 114.0 & 141.7 & 117.4 & $-29.5^{\star * *}$ & -1.1 & $-7^{* *}$ \\
\hline
\end{tabular}

$\mathrm{a}, \mathrm{b}$ and $\mathrm{c}=$ significance of differences at the levels of $0.05,0.01$ and 0.001 , respectively

Beside the higher seed and oil yields, hybrids 81, 88 and 56 demonstrated a decreased plant height and a shorter growing season. These positive changes are important for the sunflower breeding program because they allow easier harvesting and earlier clearing of the fields for subsequent agrotechnological activities.

\section{CONCLUSION}

Using the direct organogenesis method in interspecific hybridization, fertility restorer lines were developed which possess very good combining ability in hybridization and resistance to some economically important diseases and parasites on sunflower. An early flowering line, R107, was developed which possesses $100 \%$ resistance to Orobanche. Hybrid 81, produced from line R107, exceeded the mean standard (hybrids Albena and Super Start) in seed and oil yields and it was $100 \%$ resistant to broomrape.

Line R114 demonstrated complete resistance to Phomopsis, tolerance to Phoma and $100 \%$ resistance to Downy mildew. This line had earlier dates with regard to the indices for beginning of flowering and mass flowering and a shorter vegetation period in comparison with the cultivated parent (hybrid Albena). Hybrid 88, developed line R114, exceeded the mean standard in seed and oil yields. It also had shorter plant height and growing season thanthe standard.

Line R120 developed from the cross with $H$. salicifolius, possessed an earlier date for beginning of flowering and a shorter vegetation period than the female par- 
ent (hybrid Albena). The line demonstrated resistance to Alternaria, tolerance to Phoma and $100 \%$ resistance to Downy mildew. Hybrid 56 developed from line R120 showed higher seed and oil yields in comparison with the mean standard as well as shorter plant height and growing season.

The lines developed through interspecific hybridization are valuable initial material for sunflower breeding and hybrid seed production.

\section{REFERENCES}

Todorova, Y.G., 1990. Genetic and cytogenetic investigations on genus Helianthus. Sofia, BAS (Bg).

Barov, V. and Shanin, J., 1965. Methodics of field experiment. Zemizdat, Sofia (Bg).

Bohorova, N.E., 1991. Report on cytogenetic problems in wild sunflower species and interspecific hybrids (1988-90), application of tissue culture methods and plan for 1991-1993. Consultation Meeting of the FAO-Sunflower Network, Pisa 1991.

Chandler, J.M. and Beard, B.H., 1983. Embryo culture of Helianthus hybrids. Crop Sci. 23: 1004-1007.

Christov, M., 1990. Study on the wild species from genus Helianthus with a view of their use in sunflower breeding. Ph.D. thesis, Sofia, (Bg): pp. 208.

Christov, M., 1996. Characterization of wild Helianthus species as sources of new features for sunflower breeding. In: P.D.S. Caligari and D.J.N. Hind (ads). Compositae. Biology and Utilization. Proceedings of the International Compositae Conference, Kew, July 1994, Royal Botanic Gardens, Kew 2: 547-570.

Christov, M., 1996. Hybridization of cultivated sunflower and wild Helianthus species. In: P.D.S. Caligari \& D.J.N. Hind (ads). Compositae. Biology and Utilization. Proceedings of the International Compositae Conference, Kew, 1994, Royal Botanic Gardens, Kew, 2: 603-615.

Christov, M., Shindrova, P. and Encheva, V., 1996. Transfer of new characters from wild Helianths species to cultivated sunflower. Gent. a Slecht. 32(4): 275-286.

Dozet, B., Atlagić, J. and Vasić, D., 1996. Transferring stem canker resistance from Helianthus tuberosus L. into inbred line of sunflower by embryo rescue technique. Helia 19: 87-94.

Encheva, J., Christov, M. and Ivanov, P., 1992. Use of direct organogenesis in vitro from immature embryos of interspecific and intergeneric hybrids of Helianthus annuus L. Proceedings of the $13^{\text {th }}$ International Sunflower Conference, Pisa (Italy), September, 711, vol. II: 1455-1460.

Encheva, J., Christov, M., Köhler, H., Shindrova, P., Encheva, V. and Friedt, W., 2004. Interspesific hybrids between Helianthus annuus and $H$. tuberosus: RAPD analysis, disease resistance, combining ability. BJAS. 10(2): 169-175.

Friedt, W., 1992. Present state and future prospects of biotechnology in sunflower breeding. Field Crops Research 30: 425-442.

Iliescu, H., 1992. Workshop on studies on common methodologies and population dynamics on sunflower pathogens. Bucharest, Romania, September, 29 to October, 1.

Georgieva-Todorova, J., 1993. Interspecific hybridization and its application in sunflower breeding. Biotechnology and Biotechnology Equipment 7(4): 153-157.

Georgieva-Todorova, J., 1997. Interspecific relationship in the genus Helianthus. Bulg. Acad. Sci., Sofia.

Kräuter, R., Steinmetz, A. and Friedt, W., 1991. Efficient interspecific hybridization in the genus Helianthus via "embryo-rescue" and characterization of the hybrids. Theor. Appl. Genet. 82: $521-525$.

Köhler, H. and Friedt, W., 1999. Genetic variability as identified by AP-PCR and reaction to midstem infection of Sclerotinia sclerotiorum in interspecific sunflower (Helianthus annuus L.) hybrid progenies. Crop Science 39: 1456-1463.

Korell, M., Brahm, L., Horn, R. and Friedt, W., 1996a. Interspecific and intergeneric hybridization in sunflower breeding, I: General breeding aspects. Plant Breeding Abstracts 66: 925-931

Leclerq, P., 1969. Use sterile male cytoplasmique chez le turnesol. Ann. Amelior. Plant 19: 99106. 
Newport Instruments Ltd., 1972. Use of the Newport quantity analyzer as a replacement for solvent extraction for measuring the oil and fat content of oil seeds, chocolate, meat and other materials. Newport Pagnell, England.

Pančenko, A.N., 1973. Rannija diagnostica zarazihoustoycivosti pri selekcii podsolnecnika. Zbornik VNIIMK: 107-115.

Sackston, W.E., 1992. On a treadmill: Breeding sunflower for resistance to diseases. Ann. Rev. Phytopatology 30: 529-551.

Seiler, G.J., Pomeroy, J. .and Marinković, R., 1992. Valuable sunflower germplasm collected from the Northwestern United States. Helia 15(17): 1-6.

Škorić, D., 1987. In: Progress report 1984-1986. FAO Subnetwork. Genetic evaluation and use of Helianthus wild species and their use in breeding programs (Ed.D. Škorić). FAO, Rome, Italy 1: pp. 17.

Škorić, D. and Rajčan, I., 1992. Breeding of Sclerotinia tolerance in Sunflower. In: Proceedings of the $13^{\text {th }}$ International Sunflower Conference, Sept. 07-11, 1992, Pisa (Italy),Vol. I: 1257-1262.

Škorić, D., Atlagić, J., Marinković, R., Dozet, B. and Mihaljčević, M., 1995. In: FAO Working Group: Evaluation of wild Helianthus species, Progress Report 1994, July 25-28, 1995, Bucharest (Romania), pp. 11-25.

Tourvieille, D., Vear, F. and Pelletier, C., 1988. Use of two mycelium tests in breeding sunflower resistant to Phomopsis. In: Proc. $12^{\text {th }}$ Int. Sunflower Conf., Novi Sad, Yugoslavia. 25-29 July, pp. 110-114.

Viranyi, F. and Gulya, Th., 1995. Proposed methodologies for inoculation of sunflower with Plasmopara halstedii and for disease assessment. Proposed methodologies for inoculation of sunflower with different pathogens and for disease assessment, Bucharest, Romania, 25-28 July, 1995.

\title{
NUEVOS RESTAURADORES DE GIRASOL FORMADOS POR EL MÉTODO DE ÓRGANOGENESIS DIRECTA DEL CRUZAMIENTO DE INTERESPECIES DE Helianthus annuus L. (cv. ALBENA) $\times$ Helianthus salicifolius - RESISTENCIA A ENFERMEDADES, HABILIDAD DE COMBINACIÓN
}

\author{
RESUMEN
}

$\mathrm{El}$ método de organogénesis directa en los embriones de girasol $\mathrm{F}_{1}$ no madurados, fue aplicado con éxito para la formación de nuevas formas de cruzamientos de interespecies de Helianthus annuus (cv. Albena) $\times$ Helianthus salicifolius. Tras repetida autofecundación y selección continua, fue creado un elevado número de líneas que se diversificaban entre si significativamente. Algunas de ellas poseían resistencia a Phomopsis, Phoma, Alternaria y angiosperma parásita, el Hopo del girasol, tanto como buena habilidad de combinación. Los híbridos engendrados de las nuevas líneas, mostraron el incremento de índice para el rendimiento de semilla y aceite, de $114.0 \%$ y $117.8 \%$, en relación con el valor medio del estándar (híbridos comerciales Albena y Super Start), corta vegetación y altura reducida. Las combinaciones de estos cambios positivos son deseables en el trabajo de selección en girasol. 
NOUVELLES LIGNÉES RESTAURATRICES DE TOURNESOL DÉVELOPPÉES PAR ORGANOGÉNÈSE DIRECTE DU CROISEMENT INTERSPÉCIFIQUE Helianthus annuus L. (cv. ALBENA) x Helianthus salicifolius RÉSISTANCE À LA MALADIE, APTITUDE COMBINATOIRE RÉSUMÉ

La méthode d'organogénèse directe chez les embryons de tournesol $F_{1}$ immatures est utilisée avec succès dans la réalisation de nouvelles formes depuis le croisement interspécifique Helianthus annuus (cv. Albena) $\times$ Helianthus salicifolius. Après autofécondation répétée et sélection continue, un grand nombre de lignées significativement différentes ont été réalisées. Certaines des nouvelles lignées possédaient une résistance envers les Phomopsis, Phoma, Alternaria et l'angiosperme parasite de l'orobanche ainsi qu'une bonne aptitude combinatoire. Les hybrides créés à partir des nouvelles lignées ont montré une augmentation de l'indice de rendement en graines et en huile de $114,0 \%$ et de $117,8 \%$ relativement à la valeur moyenne standard (hybrides commerciaux Albena et Super Start), une végétation brève et une diminution de la hauteur. Des combinaisons de ces changements positifs sont souhaitables dans le travail de sélection sur les tournesols. 
